\title{
ISLAMIST PARTY, ELECTORAL POLITICS AND DA'WAH MOBILIZATION AMONG YOUTH The Prosperous Justice Party (PKS) in Indonesia
}

\author{
Noorhaidi Hasan \\ UIN Sunan Kalijaga, Yogyakarta - Indonesia
}

\begin{abstract}
The involvement of the Prosperous Justice Party (PKS, Partai Keadilan Sejahtera) in the electoral democratic system in Indonesia raises a question whether it is possible for a political party with a deeply religious ideology to liberalize and entertain democracy. The decision to enter politics does not infrequently entail an abandonment of ideological purity. It represents an acceptance of the political order and power sharing-based politics. While identity and ideology are instrumental in political mobilization for PKS, it has no choice but to negotiate and interact with other political actors through coalitions and parliamentary politics. A modern party involved in a competitive and rule-based system, it is also required to broaden its electorate and reach out to non-Islamist voters. It is intriguing in this context to explore the party's strategy to maintain its Islamist platforms and the base of support while allying itself with distinctly non-Islamist ruling elites, and engage in the pragmatic ruling coalition. Understanding the paradoxical roles of an Islamist party when involved in the on-going electoral democratic process, this paper also looks at the future of political Islam in Indonesia.
\end{abstract}

Keywords: Islamism, PKS, Election, democracy.

\section{Introduction}

Indonesia's political system has undergone transformations in recent years as a result of the opening of political opportunity in the post-Suharto era and the increasing adoption by the state of more or less democratic forms of government. In tandem with the spread of political party-based forms of political activity, a dozen political parties that represent different ideologies and interests have arisen, including 
those explicitly espousing the application of the shari ab (Islamic law) and other conservative positions. One such example is the Justice Party (PK, Partai Keadilan) whose emergence represents the growing strength of political Islam on the political landscape of Indonesia. This party is fundamentally different from the other Islamic partiesUnited Development Party (PPP, Partai Persatuan Pembangunan), National Awakening Party (PKB, Partai Kebangkitan Bangsa), National Mandate Party (PAN, Partai Amanat Nasional) and Moon and Crescent Party (PBB, Partai Bulan Bintang) - in terms of its historical roots, its ideology, its political goals and the broader range of the electorate it appeals. In fact, it constitutes a permutation of the da'wah (Islamic proselytizing) movement exemplifying Islam as a total way of life, which began to gain ground on Indonesian university campuses in the 1970s. ${ }^{1}$ Widespread influence of this da'wah stream facilitated the efflorescence of the Muslim Brotherhood ideas and activism adopting the name tarbiyah (Islamic education), the Arabic word for education under a teacher who provides moral guidance. ${ }^{2}$ In the changing atmosphere of state-Islam relationship during the last decade of the New Order regime, marked by its accommodative stance towards Islam, the movement developed very fast to the extent that it emerged as a striking stream in the campus life of Indonesia during the 1990 s. $^{3}$

1 This da'wah stream began to flourish across the Indonesian archipelago, from the Salman Mosque of the Bandung Institute of Technology that introduced the programme of the Latihan Mujabid Dakwah (Training of Da'wah Fighters) at the beginning of the 1970s. Having evolved into the network of the Lembaga Dakwah Kampus (Campus Da'wah Board), it provided the model for the dissemination of the usrah (family) system and da'wah activities and facilitated an increase in students' observation of their Islamic obligations, in their wearing of the jilbab, and in the spread of Islamist books.

2 On the tarbiyya movement, see Rifki Rosyad, A Quest for True Islam: A Study of the Islamic Resurgence Movement among Youth in Bandung, Indonesia (Canberra: ANU E Press, 2006); Salman, "The Tarbiyah Movement: Why People Join This Indonesian Contemporary Islamic Movement," Studia Islamika 13, 2 (2006): pp. 171-241; and on its transformation into PKS see Ali Said Damanik, Fenomena Partai Keadilan Transformasi 20 Tabun Gerakan Tarbiyah di Indonesia (Jakarta: Teraju, 2002); Mathias Diederich, "A Closer Look at Dakwah and Politics in Indonesia: The Partai Keadilan," Archipel 64 (2002): pp. 101-15; and Yon Machmudi, Islamising Indonesia: The Rise of Jemaah Tarbiyah and the Prosperous Justice Party (Canberra: ANU E Press, 2008).

3 Modelled after the cellular network of the Egyptian Muslim Brotherhood, the usrah developed by the tarbiyah movement provided Islamic training that emphasized the 
As the party that evolved out of the movement that drew its inspiration from the Brotherhood, PK endeavoured to position Islam at the centre of the Indonesian political landscape and defined it primarily as a political ideology. It adapted a classical vision of Islam as a complete and universal system which comprehensively governs all spheres of social, political, economic and cultural life. Shari ${ }^{-}$h is emphasized in this context as the only alternative system that leads Muslims to get rid of various current problems and catastrophes afflicting their lives as an impact of the implementation of secular systems. It is believed that on the basis of the shari ${ }^{\top} a h$, Muslims will be able to challenge the domination of the Western powers that have been collaborating with the Zionists to undermine Islam and the Muslim ummah. ${ }^{4}$ Implicit in this rhetoric is a protest against the existing nation-state system, deemed to be a weapon of the imperialist West to divide Muslim nations and demolish the khilafah (caliphate). It is not surprising that PK was very much concerned with the issue of Islamic solidarity and re-establishment of the caliphate. ${ }^{5}$ There is thus a clear natural tension in the kind of political manifesto of PK between the ideal of the ummah and the reality of the nation-state. PK was in fact known as an avant-garde party of ikhwan and akbawat, popular terms used by tarbiyah members to address their fellow activists. Interestingly, by pushing the Islamist viewpoints and emphasizing its exclusiveness as an Islamist party, PK garnered only 1.4 per cent of the overall votes in the 1999 elections and thus failed to meet 2 per cent of the electoral threshold.

The result of the 1999 elections forced PK to reconstitute as the Prosperous Justice Party (PKS, Partai Keadilan Sejahtera) whose vision is nonetheless to strengthen the ideology, thought and system developed by its predecessor aspiring to apply Islam in the social, political and legal system of Indonesia. ${ }^{6}$ Yet, a different emphasis is put

purity of God (tawhidid) and strict implementation of Islamic precepts. Particular Islamic doctrines, including da'wah, jihäd, ghazw al-fiker and jähiliyah, were highlighted as a means for the movement to organize and train its following.

${ }^{4}$ Aay Muhammad Furkon, Partai Kedilan Sejabtera: Ideologi dan Praksis Politik Kaum Muda Muslim Indonesia Kontemporer (Jakarta: Teraju, 2004), pp. 149-157; M. Imdadun Rahmat, Ideologi Politik PKS, Dari Masjid Kampus ke Gedung Parlemen (Yogyakarta: LKiS, 2008), pp. 55-57.

${ }^{5}$ Furkon, Partai Keadilan Sejabtera; Rahmat, Ideologi Politik PKS, p. 58.

${ }^{6}$ Rahmat, Ideologi Politik PKS, p. 114. 
on the aim of the party. Claiming to be a party of moral reform, it is aimed at educating the public through da'wah, about what a government based on the moral principles of Islam would look like, rather than obtaining political power. With the slogan "clean and caring", the party launched popular campaigns focusing on the national issues of a feeble economy and rampant corruption. ${ }^{7}$ While actively involved in humanitarian operations in numerous disaster areas across the Indonesian archipelago, it simultaneously expressed concern about the world politics, by sending warning messages about the danger of U.S. foreign policy for the Muslim world. Within this context, it actively organized peaceful demonstrations against American invasions of Afghanistan and Iraq as well as Israeli attacks on Palestine. For PKS, U.S. tendency to side with Israel has served as the main catalyst for protracted conflicts in the Middle East. Solidarity for Palestine has become the main theme in the party's discourses of foreign policy affairs.

During the campaigns in the run-up to the parliamentary elections in April 2004, PKS reiterated its vision as a party of moral reform concerned with the fight against nation's ultimate problems, including corruption, collusion and nepotism. It conveyed the image of a disciplined organization, unsoiled in dress and thinking, free of corruption and morally pure. This strategy worked well. The party won significant votes, as much as 7.34 per cent. ${ }^{8}$ More surprisingly, it scored a landslide victory in Jakarta, the Indonesian capital, capturing 24 per cent of the vote. Support for the party came not only from the core constituency among the ikhwan and akbawat in the network of the tarbiyah movement and aspirant Islamists, but also from swing voters, including both urban (upper) middle class in elite neighbourhoods and poor migrants in slum areas. With 45 seats in parliament, PKS came to engage in the nationalist ruling coalition led by the Democratic Party's founder, Susilo Bambang Yudhoyono, who won the presidential

\footnotetext{
7 Elizabeth Fuller Collins, "Islam is the Solution, Dakwah and Democracy in Indonesia", Kultur, the Indonesian Journal for Muslim Cultures 3, 1 (2003): pp. 148-82; Elizabeth Fuller Collins and Ihsan Ali Fauzi, "Islam and Democracy, the Successful New Party PKS is a Moderate Alternative to Radical Islamism", Inside Indonesia 81 (2005); and Ary Hermawan, "PKS dan Perubahan Paradigma Gerakan Islam", Republika (10 April 2004), p. 4.

${ }^{8}$ Francois Raillon, "Islam and Democracy: Indonesia's 2004 Election and Beyond," Paper presented at EIAS Special Briefing (Brussels: EIAS, 2004), p. 2.
} 
elections in September 2004 with his running mate Jusuf Kalla from the Professional Party, Golkar.'

This paper is aimed at examining the way PKS has negotiated its Islamist identity and ideology with power sharing-based pragmatic politics. Identity and ideology are certainly instrumental in political mobilization, and even more so for an Islamist party PKS. As a modern party involved in the electoral democratic system, however, it has no choice but to interact with other political actors through coalitions and parliamentary politics. It is also required to broaden its electorate and reach out to non-Islamist voters. It is intriguing in this context to explore the party's strategy to maintain its Islamist platforms and the base of support while allying itself with distinctly non-Islamist ruling elites, and engage in the pragmatic ruling coalition. Understanding the paradoxical roles of an Islamist party when involved in the ongoing electoral democratic process, this paper also looks at the way in which young Islamists have sought to synthesize between Islamic revival and democracy.

\section{Negotiating Islam and Nation-State}

PK's failure to win significant votes in the 1999 elections gave its successor a lesson that its electoral basis was not adequate to support the party's expansion. It was confined to those active in the tarbiyah movement and sympathizers that had been spread along diverse professional and socio-economic status. In fact, the image as an exclusivist party of pious Muslims committed to Islam proved to be the first obstacle for PKS to reach out to non-Islamist voters. While nationalist political rivals remained hostile and suspicious to its potential hidden agenda of establishing an Islamic state, the party lacked broadly based-social networks and sufficient financial resources

9 The consultative assembly (Majlis Shura) of the party had agreed to support Yudhoyono's bid for presidency on the basis of a five-point memorandum of understanding $(\mathrm{MoU})$ signed by Hidayat Nur Wahid and Yudoyono himself. Both parties were committed to the endeavour to build a clean, caring and professional governance, demonstrated, among other things, by the readiness to fire corrupt cabinet members and determination not to abuse Muslims and Indonesian people in general. They were also committed to protect the sovereignty of the Republic of Indonesia amid the changing constellation of world politics and continue the process of democratization and reformation in the sake of the supremacy of civil society, coined as the 'masyarakat madani'. In the last two stated points, both parties agreed to boost the nation's morality and societal quality and welfare in respect of law enforcement as well as human rights, and to support the Palestinians' struggle for independence. 
to mobilize its political machine. Nor had it a certain association to established Muslim organizations, primarily represented by the Nahdlatul Ulama (NU) and Muhammadiyah. Members of the organizations have their own political channels through the parties set up or sponsored by their leaders-PKB, PAN, PPP and PBB.

In an attempt to cope with some reservations shown by its secular nationalist rivals and Indonesian people in general, PKS sought to create a new image as a moderate Islamist party adopting the national and democratic rhetoric. Reflecting its commitment to the principle of a secular political order which becomes a prerequisite for the establishment of a liberal democracy, ${ }^{10}$ the party began to acknowledge the secular format of the Indonesian nation-state and state ideology the Pancasila, as well as the 1945 Indonesian Constitution as the framework of its political participation in the electoral democratic system. Despite the principle of God's absolute sovereignty held by most Brotherhood theoreticians, PKS saw no contradiction between Islam and democracy. It argues that the community has the right to define political institutions via democracy, which is considered an instrument to infuse Islam into the Indonesian politics. ${ }^{11}$ Reference has been made to Yusuf Qaradawi, known as a moderate Brotherhood thinker, who acknowledges the notion that the people are entrusted with the right to govern themselves and this does not derogate from God's ultimate sovereignty. This progressive position represents a more inclusive politics in the Muslim world where democracy has increasingly been perceived to incorporate the values that Islam advocates, including consultation, enjoining what is good and prohibiting evil, and resisting unbelief. ${ }^{12}$

Despite the importance of Islam as a source of identity and legitimacy in PKS's discourse, the party's vision is tinted with national narratives. In its charter and articles of association, PKS insists that the aim of its establishment is to realize the national ideals as declared in the Indonesian Constitution for the sake of the burgeoning of civil

10 Ziya Öniş, "Globalisation and Party Transformation, Turkey's Justice and Development Party in Perspective," in Peter Burnell (ed.), Globalising Democracy (London and New York: Routledge, 2007).

11 Interview with Cholid Mahmud, one of the PKS leading figures in Yogyakarta, March 2008.

12 James Piscatori, "Islam, Islamists and the Electoral Principle in the Middle East," ISIM Paper 1 (Leiden: ISIM, 2000). 
society. The very existence of the Republic of Indonesia is emphasized as nation-state entity and territorial unity altogether that need to be protected and defended from any destruction by nation enemies. Its strategic goal is both to establish an independent, caring and prosperous civil society that respects justice and to realize the principles of honest, clean, transparent and responsible good governance. ${ }^{13}$ In what seems to be ambiguous terms, PKS also describes itself as a religious nationalist party, which rejects a secular, deceitful political practice. It claims to stand at the forefront to struggle for justice and prosperity within the unity of ummab and nation. Attempting to synthesize Islam and nationalism, the party believes that, if implemented correctly, Islam can serve as a solution to various economic, social and political problems currently facing Indonesia. There is certainly a democratic dilemma in PKS's adoption of Islamist ideology and participation in democratic politics. ${ }^{14}$ But its political behaviour turned more pragmatic in tandem with the ongoing democratic consolidation.

Borrowing the framework introduced by Baker when analysing the dynamics of political Islam in Egypt, it is intriguing to look at the extent to which the rise of PKS may represent the birth of new Islamists who hold out a longer-term vision for reform. As Baker argues, new Islamists' adoption of a participatory and pragmatic approach distinguishes them significantly from the first generation of Islamists that sought political power to reform the social order along Islamic lines. They are more content to contest elections and take up whatever seats or offices they may win. Instead of cultivating a defensive discourse perceiving Islam as a religion under attack that requires its followers to defend and fight against enemies, they call Muslims to participate in the task to improve society. ${ }^{15}$ The character of their thinking might be summarized in terms of holism, inclusivity and dialogue. Religion is seen as just one part of the solution. It needs to be regarded in conjunction with national interests, economic realities and cultural traditions. Given their emphasis on national

${ }^{13}$ See PKS's articles of association, Article 3; see also the explanation of this article in the basic policy of the party. See http://www.pk-sejahtera.org.

${ }^{14}$ See Ahmad-Norma Permata, "Ideology, Institutions, Political Actions: Prosperous Justice Party (PKS) in Indonesia," Asien 19 (2008): pp. 22-36.

15 R. Baker, Islam Without Fear: Egypt and the New Islamists (Cambridge, MA: Harvard University Press, 2003). 
interest, they are open not only to collaborate with other political forces and non-Muslims as equal partners, but also to dialogue and collective deliberation. No doubt, the new Islamists represent, as Mandaville has noted, "a broader generational and strategic shift identifiable in Muslim movements across several settings today". ${ }^{16}$

As a matter of fact, PKS has introduced a dramatic break with its rigid ideology around the concept of the totality in Islam (Islam kaffah) as developed in the tarbiyah movement. It believes that the Pancasila, as the state philosophical foundation, can function as the main inspiration for the whole process of statecraft and governance. Yet for PKS, the Pancasila should be taken not as the sole ideology that serves as the bastion of secularization blocking any other political aspirations. It suggests instead that the application of the Pancasila and democracy can work altogether with that of Islamic values and principles. Being aware that the issue of the Jakarta Charter (Piagam Jakarta) has long overshadowed the relationship between Islam and the state in Indonesia, PKS preferred not to prolong the debate on the seven words "dengan kewajiban menjalankan syariat bagi pemeluknya" in the Charter, which stipulate the obligation for adherents of Islam to follow the shari ${ }^{7}$ ah. ${ }^{17}$ In the atmosphere of reform that heralded a freedom of expression, Muslim politicians from a number of Islamic parties revived the debate in their endeavour to give the shari ${ }^{-} a b$ a constitutional status. Like the attempts made by the first generation of Islamists, their endeavour also ended in failure. ${ }^{18}$ In an elegant manoeuvre, PKS came up with the idea to implement the Madinah Charter (Piagam Madinah), a constitution that essentially established the Madinah city-state under the leadership of the Prophet Muhammad. ${ }^{19}$ The Charter was the first written constitution in Islam

\footnotetext{
16 Peter Mandaville, Global Political Islam (London and New York: Routledge, 2007).

17 Together with the other seven Islamic parties (PPP, PBB, Masyumi, PKU, PNU, PUI and PSII 1905), PKS signed a joint-declaration to call for a reinsertion of the seven words in the Jakarta Charter into the amended 1945 Indonesian Constitution during the people's consultative assembly annual session in August 2002 at a meeting in Al-Azhar Mosque in Jakarta. See http://www.pk-sejahtera.org.

18 Nadirsyah Hosen, "Religion and the Indonesian Constitution: A Recent Debate," Journal of Southeast Asian Studies. 36, 3 (2005): pp. 419-40.

19 PKS's chairman, Tifatul Sembiring, reiterated his party denial of the importance of the Jakarta Charter in a seminar in London on Indonesian politics and economic progress. According to him, what PKS has endorsed is the application of the Madina
} 
and arguably the first constitutional law in society. Before Prophet Muhammad's arrival from Mecca, Yathrib (later known as Madinah) had a population of 10,000 that was organized into approximately 22 tribes. Approximately half the population was Jewish and half was Arab. The introduction of the Charter established rules of government and addressed specific social issues of the community in an attempt to put to an end the chaos and conflict that had been plaguing the region for generations. ${ }^{20}$ By referring to the Charter, PKS demonstrates the compatibility of Islam with democracy and, at the same time, its determination to abide by civic principles of pluralism as well as peaceful coexistence among and within diverse religious groups.

In response to continued suspicion of its political rivals about its hidden agenda to establish an Islamic state, PKS insists what is more important is not how Islam is institutionalized as a state system, but how its basic values, which include the tendency to realize a just and clean governance, are embedded in the political practices of the state and in the management of societal affairs. This is emphasized as the meaning of the party's commitment to "build a better social and political life in accordance with Islamic values". ${ }^{21}$ PKS does not deny the importance of the shari ${ }^{\top} a$. Convinced that Islam has spirited the Indonesian Constitution and all of its derivative legal products, PKS aspires to include the shari ${ }^{\top}$ ah in the Indonesian political system and practice. What Indonesia desperately needs is, according to the party's founder Hidayat Nur Wahid, not the application of the shari ah at the symbolic level, but rather at the substantial level as a moral endorsement within the framework of nation-state and democratic system. He believes that the shari ${ }^{-}$ah can be implemented through the enforcement of justice rule and good governance that guarantee the fulfilment of civil rights. ${ }^{22}$ In PKS's point of view, this is the most suitable and realistic strategy to prepare the societal awareness towards the comprehensive application of the shari ${ }^{\top} a h$.

Charter that in essence guarantees religious pluralism. See PKS, "Mengkaji Indonesia dari Inggris," http://www.pk-sejahtera.org (20 June 2008).

${ }^{20}$ For a further account on the Madina Charter, see William Montgomery Watt, Muhammad at Medina (Oxford University Press, 1956); and Efraim Karsh, Islamic Imperialism: A History (Yale: Yale University Press, 2006).

${ }^{21}$ See "Kebijakan Dasar PKS", in http://www.pk-sejahtera.org.

22 Hidayat Nur Wahid, "Shari'a Should Stress Morals, Not Law," The Jakarta Post (30 August 2007). 
Given its major emphasis on the supremacy of the shari ${ }^{-} a b$ with regard to the importance of moral values and principles in politics, PKS has remained an intriguing puzzle for political scientists and observers as well as its political rivals. They are questioning PKS's ability to be a national party that respects the principles of religious freedom as part of a broader agenda of individual rights and democratization. ${ }^{23}$ Continued debates over its ambivalence towards democracy notwithstanding, PKS has increasingly developed an inclusive political platform and altered its basic perception about what is permissible in a democratic environment. It has no doubt learnt how to be involved in the electoral democratic games and become a proactive force contributing to the process of further democratic deepening in Indonesia. The democratization itself necessarily involves a learning process. As we will see, PKS has no longer hesitated to progressively embrace liberal democratic norms in the process of trying to construct broad electoral coalitions within the boundary of parliamentary democracy.

\section{Electoral, Parliamentary and Cabinet Participation}

In an attempt to set up a party institution and organizational infrastructure, PKS first mobilized dedicated cadres that had joined small cell units called usrah, literally meaning family, in the tarbiyah movement. Most of them are educated members involved in cultivating a striking Islamic environment in their own social domains, such as family, professional organization and office. Yet, even groups that were relatively well-established adopted a new process of institutionalization, including registration with the appropriate government agency, the establishment of a formal office or headquarters, and efforts at increasing local presence through regional offices. The first action by PKS was to establish a formal structure within the party, including administrative divisions of the headquarters office, an executive committee and a consultative council, called shîra This model closely followed the internal structure of the Brotherhood in Jordan and Egypt. Benefiting from its predecessor's institutional

\footnotetext{
${ }^{23}$ For instance, Sadanand Dhume, "Radical March on Indonesia's Future," Far Eastern Economic Review 168, 5 (May 2005): pp. 11-19; "PKS and the Future of RI's Democracy," Jakarta Post (5 December 2005); and Zachary Abuza, "Politics and Violence in Indonesia: An Emerging Jihadist-Islamist Nexus?," NBR Analysis 15, 3 (September 2004): pp. 1-54.
} 
structures, PKS's executive boards immediately exist in 30 provinces, 312 districts and municipalities, and 2,155 sub-districts across Indonesia, plus 13 representatives abroad called Information Centre of PKS (PIPKS). These branch offices served as the centre for recruitment and consolidation of the party's cadres.

The role of leadership in helping PKS to moderate its political platform and transform its image as a moderate Islamist party should not be overlooked. Hidayat Nur Wahid and M. Anis Matta, the chairman and secretary general of the party respectively, are two noted activists that began to take a leading role in the tarbiyah movement in the changing political atmosphere of the 1990s. They represent a new generation of Indonesian Islamists adopting a participatory and pragmatic approach in politics. Other important personalities in PKS's leadership include former student activists involved in anti-Suharto mass movement in 1998. Among these cohorts are Zulkifliemansyah, Rama Pratama, Andi Rahmat and Fahry Hamzah himself, the leading figure in the tarbiyab-linked student organization, the Indonesian Muslim Student Action Union (KAMMI). Beyond these circles, PKS recruited academics, businessmen and professionals sympathetic to their goal of cleaning Indonesia's political practices. The party's leadership recruitment process therefore did not rely on traditional hegemonic political ties nor on status quo endorsements. It tried to do the best in order to put forth fresh leaders that were not offspring of the old elite. Seen from this perspective, the rise of PKS appears to be the best example of what can be accomplished in the kind of open democratic system Indonesia is establishing. It represents an end to the elitist monopoly by making the process more proletarian and transparent.

The broad network of cadres and party's structure reaching the village level helps PKS's campaign to promote popular issues concerned with poverty, education and corruption. This campaign provided a new hope for many people discontented with the government led by Megawati Sukarnoputri of PDI-P, known as a nationalist-secular leader. Her effort to get rid of economic pressures by selling state properties and profitable companies provoked some criticism. Known as a president whose performance was not convincing and believed to be under the influence of her husband, Taufik Kiemas, in decision-making, she failed to convince the public that her government and her party were different or any better than 
other political elites and parties. ${ }^{24}$ Together with the Democratic Party set up by Yudhoyono, PKS became the symbol of change for the Indonesian electorate that wanted new faces and a different way of conducting politics. The results of 45 parliament seats at the national, 157 at the provincial and 900 at the district levels were the appropriate rewards for the working of PKS's cadres and institutional network across Indonesia and its success to offer a new hope for the future of Indonesian politics.

At the outset of its political participation in the state institution, PKS succeeded in bringing its chairman, Hidayat Nur Wahid, into a prestigious position as the speaker of the People Consultative Assembly (MPR, Majelis Permusyawaratan Rakyat). His candidacy was supported by medium-sized parties, including the Democratic Party, PAN and PPP, plus the group of regional representatives or senators (DPD, Dewan Perwakilan Daerah) in MPR. The rise of Nur Wahid to the position as the speaker of the assembly confirmed the move of PKS into a world of mainstream politics frequently marked by pragmatism and compromises. His first manoeuvre was to withdraw from his chairmanship at PKS and move to the advisory council of the party. Tifatul Sembiring, PKS's vice-chairman for Sumatra, came as his replacement. This manoeuvre was believed not only instrumental for his attempt to demonstrate his commitment to stand above his own party's interest and devote solely to nation's agenda of reform and democratization, but was also important to show PKS's determination to rely on party's platforms and programmes, rather than certain charismatic personalities.

Based on a similar argument, PKS leaders legitimized the party's involvement in the ruling coalition. While they found themselves subject to the realities of day-to-day politics of Indonesia and institutional rules of democratic games, they have been convinced that participation in the cabinet coalition would add to their political learning experience especially in the art of governing. It is also believed as a means to conquer the fears some observers and other coalition partners have still put forward regarding the party's potential threat to Indonesia's democracy. ${ }^{25}$ PKS was given three cabinet portfolios,

\footnotetext{
${ }^{24}$ Raillon, "Islam and Democracy," p. 4.

25 Zulkifliemansyah, "Overcoming the Fear: PKS and Democratization," The Jakarta Post (12 December 2005).
} 
including the ministries of agriculture, housing, and youth and sport. The party placed three leading cadres into these positions. They are Anton Apriantono, a Bogor Institute of Agriculture's academic graduating from the University of Reading, England, as the minister of agriculture; Muhammad Yusuf Asy'ari, a former financial manager at the largest private national TV company, RCTI, as the minister of housing; and Adhyaksa Dault, a former leader of the Golkar-linked National Committee of Indonesian Youth (KNPI), as the minister of youth and sport.

Despite their success to convince other political forces about their commitment to the nation, and thus overcoming the sense of being exclusive, PKS leadership has no political blueprint for social transformation and their understanding of governance is shaped by their flexible, if not pragmatic, standpoints. As a result, they seemed ambivalent towards a variety of crucial issues, including the increase of oil prices and cash transfer programmes initiated by Yudhoyono's government. Only on certain divisive symbolic issues did they stand at the forefront to express their political standpoints. One such example is on the issue of pornography, Palestinian conflict and Ahmadiyah. PKS was persistent to call for a ratification of anti-pornography bill and solidarity to Palestinian people against Israeli attacks. They actively mobilized members to call for a disbanding of Ahmadiyah considered a deviant sect threatening Muslim faith.

PKS's image as a party with a reputation of being clean and polite faced the first real test when its young members involved in Realpolitik in parliament got closer to the levers of power. While PKS legislators, both at the national and local levels, were challenged to carry out their promises of being clean and at the vanguard of the total reform, the temptations of power and wealth have so far proved unprejudiced. Like members of other Islamic parties, they also have been implicated in widespread corruption scandals in parliament. ${ }^{26}$ As evidence, PKS's legislators in Commission IV were forced to return gratification money as much as Rp 1.9 billion in relation to the uncovered scandal of the development of Bagan Siapi-api port in Sumatra.

\footnotetext{
${ }^{26}$ Yet, if compared to legislators from other parties in parliament, including the Islamic ones, PKS members have relatively been clean. While a dozen legislators have been arrested by the Committe of Combatting Corruption (KPK, Komisi Pemberantasan Korupsi) for corruption scandals over the last five years, none of them was from PKS.
} 
For the sake of fulfilling its political targets, PKS has appeared to be more pragmatic, especially in its endeavour to win various direct elections at regional levels (pilkada). It did not hesitate to help any candidates capable of paying by lending through the party institution and its broad mobilization network, and collaborate with other parties, including the nationalist-secular PDI-P and the religious Christian Prosperous Peaceful Party (PDS, Partai Damai Sejahtera). In this way, PKS claimed to have succeeded in promoting its members and sympathizers to the posts of governors and heads of district across Indonesia. PKS scored a prestigious victory in Depok, West Java, where its leading cadre and former minister of forestry in Abdurahman Wahid's presidency, Nur Mahmudi Ismail, was elected as the city's mayor. In another praiseworthy manoeuvre, PKS promoted former police high-ranking officer, Adang Daradjatun, to be the candidate of Jakarta's governor with his runner mate, Dani Anwar. At that time, the party was quite confident of not collaborating with any other parties, which together promoted Fauzi Bowo as Jakarta's hopeful governor with his running mate, Prijanto. Despite its failure to win the elections in the special region of Indonesia's capital, PKS also participated in the 2008 election race in West Java by promoting his own cadre, Ahmad Heryawan. In collaboration with the National Mandate Party promoting Dedi Yusuf as Heryawan's hopeful running mate, PKS won the elections this time. This success preceded another victory by PKS in promoting Syamsul Arifin and his running mate, Gatot Pudjonugroho, to the post of governor and vice-governor of North Sumatra in the direct elections in the same year.

Contrary to what may be assumed, PKS has never been on the forefront to call for the application of shari'ah bylaws that loudly resonated in various regencies, including Solok in West Sumatra, Indramayu, Garut and Tasikmalaya in West Java; Banjarmasin and Banjar in South Kalimantan; and Maros and Bulukumba in South Sulawesi. The pioneers of the application of these regional regulations governing various aspects relating to the shari'ah, such as dress code, Qur'anic literacy and the ban of opening stalls during fasting month Ramadan, have frequently been the political elites of Golkar and other secular parties. Manoeuvre of this sort has appeared to be an effective strategy to demonstrate their commitment to Islamic affairs. ${ }^{27}$

${ }^{27}$ Robin Bush, "Regional Sharia Regulations in Indonesia: Anomaly or Symptom?" in Greg Fealy and Sally White (eds.), Expressing Islam, Religious Life and Politics in Indonesia 
However, PKS never challenged such campaigns for the shari'ah deemed by its elites as a constitutional way towards the comprehensive application of the shari'ah. Again, one of its members insisted that the main concern of PKS was not with the application of such bylaws, but rather the attempt to conduct da'wah to diverse segments of Indonesians that eventually accept the supremacy of the shari'ah as a total way of life. ${ }^{28}$ PKS's reluctance to stand at the forefront to call for the application of the shari'ah bylaws was clearly shaped by its sense of insecurity in the face of the state and the outside world, which remain suspicious to PKS's hidden agenda to transform the secular format of Indonesia into a fully Islamic state.

PKS's political pragmatism provoked criticism from the party's members and sympathizers. Debates have abounded in various blogs concerning the involvement of the so-called da'wab party PKS in electoral politics--whether da'wah commitment will influence politics or rather politics will steer the party away from da'wah. ${ }^{29}$ Fears have mounted whether the legislators representing PKS in the parliament remain consistent to be preachers (du'ah) committed to Islamizing social sphere through political terrain or they are simply politicians pretending to be preachers. Some bloggers are even questioning the nature of the struggle for the supremacy of God's teachings through an un-Islamic democratic game. PKS's manoeuvre to collaborate with secular parties, if not the religious Christian party like PDS, appeared to be the most concerned that provoked the heated debates. In fact, more and more PKS members and sympathizers are worried that this short-term power-oriented political manoeuvre would steer the party's struggle away from its main mission to improve the Indonesian political system and practice. They are of the opinion that this kind of coalition simply demonstrates the hypocrite characters of politicians and their ambition to power.

Debates on PKS's pragmatism reflect the common problem faced by an Islamist party when moving beyond the phase of a social movement to seek direct involvement in the political order. The choice

(Singapore: ISEAS, 2008), pp. 174-91; Michael Buehler, “The Rise of Shari'a Bylaws in Indonesian Districts: An Indication for Changing Pattern of Power Accumulation and Political Corruption," South East Asia Research 16, 2 (2008): pp. 255-285.

28 Interview with Cholid Mahmud, Yogyakarta, March 2008.

${ }^{29}$ See, for instance, debates at http://www.pkswatch.blogspot.com. 
to enter politics is fraught with problems, particularly since it requires compromise-in all senses of the word-of ideological beliefs, preferences, modus operandi and even goals. Being involved in the existing political system, an Islamist party is demanded to accept the political order as a legitimate venue to work with. Since power-sharing even with groups whose views are different seems to be a norm in politics, compromises in belief and ideology are inevitably to be made. Through entry into politics, an Islamist party implicitly recognizes that political priorities will often supersede the religious, that, and that daily decisions will require choices between Islam and the interests of the party. In other words, political participation in the existing system signals abandonment of abstract ideals and marks entry into the murky and dissatisfying world of compromises and partial goals. ${ }^{30}$

\section{Da'wah and Social Services}

It is interesting to note that PKS's pragmatism has not necessarily moderated its image as a party that harbours a hidden agenda to establish an Islamic state. The main problem lies in its ambition to cultivate da'wah as a complementary strategy to dominate the political landscape of Indonesia. Within the framework of the tarbiyya movement, PKS has, in fact, continuously attempted to develop various da'wah activities, including halqa, dawra, pengajian (religious lectures), liqa a' (meeting), rī̌lah (tour), mabit (staying overnight), seminar and workshops. These activities are deemed necessary as a manifestation of the tarbiyah vision to build an Islamic society based on eight Brotherhood principles as laid down by Hasan al-Banna. These include (i) Da'wah Salafiyah (to refuse any activity which are in contrary to the Qur'an and the Sunna); (ii) Tariqah Sunniyah (emphasizing the necessity to practise the teachings of Muhammad); (iii) Haqiqah S Süfiyah (placing morality as an identity); (iv) Hay'ah Siyasiyah (willing internal

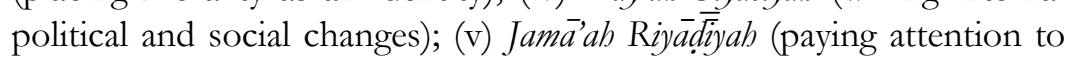
the necessity of healthy living and sport); (vi) Räbitat Tlmiyah Thaqafiyah (effort to increase science and knowledge abilities); (vii) Shirkah Iqtisadiya (ensuring economic strength and fair distribution); and (viii)

${ }^{30}$ Graham E. Fuller, The Future of Political Islam (New York: Palgrave McMillan, 2003), pp. 133-4.

$32 \mid$\begin{tabular}{l|l} 
JOURNAL OF INDONESIAN ISLAM \\
VOLUME O6, NUMBER O 1, JUNE 2012
\end{tabular} 
Fikrah Ijtima-iya (committed to contributing to resolving social problems). ${ }^{31}$

The main objectives of the PKS da'wah programme are to recruit party core members charged with the task to attract potential members and sympathizers into their circles, thus broadening the party's core constituency, and to strengthen the solidarity and consolidation among the party members. PKS has deliberately targeted youth (including students at senior secondary schools and universities) in these outreach activities since it has a long-term socio-political vision based on the idea of instilling in the younger generation the idea that societal reform along religiously prescribed lines is an obligation that should be pursued through civic activism. Part of a long-term vision of Islamizing the Indonesian social sphere, PKS's da'wah has also deliberately targeted household women, professionals and a broader audience through majlis ta'lim and religious gatherings. PKS's emphasis on da'wah as a strategy to bring change represents the shift of the Islamist tactic towards the Islamization of the society from below. Believed to gradually bring about the Islamization of social sphere as a whole, this strategic shift has occurred, keeping pace with the process of democratic consolidation in Indonesia following the upsurge in Islamist militancy after Suharto.32 Da'wah is also considered more sustainable compared to a participation in the electoral democracy and governing coalition. Within the framework of da'wah, PKS has sponsored the efflorescence of various Islamic educational, charitable, economic, social and relief institutions-all providing a combination of basic services and religious empowerment.

PKS's da'wah has so far appeared to be the key for the party's success to recruit disciplined and dedicated young cadres. ${ }^{33}$ The

31 See Fitron Nur Ikhsan, "The Prosperous and Justice Party: The New Genre of Islamic Political Party in Indonesia," Unpublished MA Thesis (Singapore: RSIS Nanyang Technological University, 2008). For a further account on the Brotherhood strategy of movement, see Hasan al-Banna, Risalab Pergerakan 2 (Solo: Intermedia, 2001); see also Ali Abdul Halim Mahmud, Perangkat-Perangkat Tarbiyah Ikhwanul Muslimin, trans. Wahid Ahmadi et al. (Solo: Intermedia, 2004).

32 Noorhaidi Hasan, "Shari'a, Militancy and Democratic Consolidation in Indonesia," Working Paper No. 143 (Singapore: S. Rajaratnam School of International Studies, 2007).

33 Critics have blamed PKS for developing a communist-type recruitment and cadrement system. One blogger even changed the meaning of PKS's abbreviation from 'Partai Keadilan Sejahtera' (Prosperous Justice Party) to be 'Partai Komunis 
recruitment process takes place mainly through various religious programmes that PKS has organized on university campuses. Most students start their involvement in the da'wah activities of the tarbiyah movement secretly ('am sirriyah) and are only allowed to demonstrate their participation when they are confident to do so ('́am jabriyah). Indeed, university campuses have long become the target of the expansion of the tarbiyah movement and other transnational Islamist organizations.

There are some circles in the structure of cadre recruitment on university campuses. The core circle designing the grand strategy to recruit members is called Majelis Shura (MS, Consultative Council) and it supervises the Majelis Besar (MB, General Council). This systematic recruitment process leads to PKS's domination over the formal organizations among students, including the Student Executive Body (BEM, Badan Eksekutif Mahasiswa), the Student Representative Body (BPM, Badan Perwakilan Mahasiswa) and the Student Islamic Activism Unit (Rohis, Kerohanian Islam), operating from the department to university levels. Having controlled the formal student activism units, PKS is able to establish linkage with university elites, including boards of deans and rectors. This linkage forms the basis for PKS to mobilize students in response to various national and international issues. ${ }^{34}$ PKS's cadre recruitment system inside the university campuses is not much different from that of outside the campus domains. Normally, the system is centred on a respected personality such as a religious teacher and its expansion is equal to the extent to which the teacher succeeds in developing his influence along the line of his pengajian (religious lesson) networks.

PKS has also sponsored the establishment of the Iqra Club, a da'wah wing among secondary students and teenagers. This group has become increasingly active in secondary schools and has helped to augment students' da'wah activities in Islamic activity units. Activists are obsessed with their dream to bring back the victory of the ummah, the effort of which begins with the inculcation of Islamic values in

Sejahtera' (Prosperous Communist Party) and its symbol from rice and crescent to be rice and a grass knife.

${ }^{34}$ Interviews with PKS's young cadres-Ahmad Pramono, Irfan Ahmadi, Muhammad Salahuddin-in Yogyakarta, 10-12 March 2008. Cf. testimony made by Arbania Fitriani posted in her Facebook note and widely spread via online networks. 
individuals. ${ }^{35}$ Hence, the Iqra Club has endeavoured to package and disseminate Islamist messages through different modes of activism. In close collaboration with the Islamic Activism Unit (Rohis) at senior high schools, it has been active to organize liqa $\bar{a}$ (meeting), mabit (overnight), rị̆lah (travelling) and mukhayyam (camping), among other activities. ${ }^{36}$ As a result of these activities, Islamic nuances have achieved a prominence in senior high schools in Indonesia today. The majority of female students have adopted headscarves.

While PKS's political platform is moderate by the standards of most Islamist political movements, its da'wah programme has some authoritarian leanings, raising doubts in the public mind about how far it would respect a pluralistic political order. For instance, the main doctrine to which PKS cadres abide by is the Arabic maxim saying

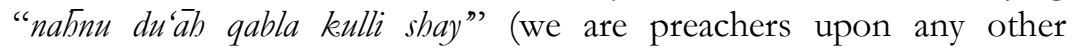
professions) and "sami"nā wa atăa"na" (we listen and we follow). This doctrine has tied cadres to be loyal, militant members of PKS. They will take for granted all instructions coming from instructors (murabbi) prepared to indoctrinate their cadres to commit for the struggle for the glory of Islam. Within this context, it appears that PKS conceives of democracy in rather instrumental terms in their quest to change Indonesian society to a more Islamist direction. In addition to this, in the foreign policy affairs its approach involves a strong anti-Israeli discourse, as noted earlier. Meanwhile sympathy and support for Palestine society has been continuously cultivated to inflame the rhetoric of victimization as a result of the global Zionist-cum-Christian conspiracy to undermine Islam and the ummah.

Related to its concern with da'wah activities, PKS has set up various centres for educating preachers prepared to help people at the grassroots level to enhance their insights into Islam. One such example is the al-Hikmah Islamic Education Institution that had been set up by tarbiyah activists at Mampang Pela, in southern part of Jakarta. Its objective is to produce da'wah cadres who are prepared to spearhead

${ }^{35}$ For an overview on the da'wah activities of Iqra Club and similar groups, see Tim Riset and Pengembangan Da'wahh Yayasan Darussalam, Menuju Teladan Darussalam (Yogyakarta: Daarussalaam Press, 2002); Izzatul Jannah, Materi Tarbiyah untuk Remaja (Surakarta: Ziyad Visi Media, 2006); and Nugroho Widiyantoro, Panduan Dakwah Sekolab: Kerja Besar untuk Perubahan Besar (Bandung: Syaamil Cipta Media, 2007).

36 Interviews with Muhammad Khairu Mumtaz and Hamdan Subhi, Yogyakarta, February 2008. 
the da'wah activities among Muslims. A significant number of da'wah campus activists came to study Islam and Arabic at Al-Hikmah. Hence, it has quickly evolved into a centre for producing preachers and a mental training for da'wah activists. Its curriculum focuses on the teaching of the Qur'an, including memorizing, refining the ability to recite the Qur'an and understand its meanings (tabfi $\bar{i} d h$, tahsin and tafsir), as well as spiritual activities, such as midnight prayer and Qur'anic recitations. ${ }^{37} \mathrm{Al}-\mathrm{Hikmah}$ has provided a model for PKS to set up a task force charged with a special duty to supply mosques and mushalla with ready-to-use preachers. To invite the preachers, a mosque only needs to contact the hotline numbers available in widely distributed pamphlets and flattered banners.

PKS has optimized the pioneering efforts made by the tarbiyahlinked Khairu Ummah da'wah institution to expand its influence among urban (upper) middle class. This institution has incorporated a dozen noted preachers and religious teachers active to deliver lectures among various social organizations and professional associations across Indonesia. With the blueprint of the da'wah expansion provided by the al-Hikmah and Khairu Ummahh, PKS has accordingly expanded its influence and its electorate basis at diverse levels of societal organizations, including the established Muslim organizations, Muhammadiyah and Nahdlatul Ulama (NU).

Realizing the potential to create an Islamic sector through education, PKS has facilitated the proliferation of the Integrated Islamic Schools, offering an alternative quality education. The PKSlinked Network of Integrated Islamic School (JSIT, Jaringan Sekolah Islam Terpadu) incorporates some 700 schools at all levels, from kindergarten to the secondary levels. JSIT evolved out of the study club popular among senior high school students who wanted to enrich their knowledge outside school times and better prepare for national exams. Called Nurul Fikri, it had been set up by tarbiyah activists. A significant number of Nurul Fikri study club graduates succeeded in continuing their studies at favourite universities across Indonesia, especially the University of Indonesia in Jakarta. JSIT has played a pivotal role in assisting da'wah activists and aspirant Islamists across Indonesia to develop their own schools through networking and information exchange. In this context, the network emerged as a sort

${ }^{37}$ Damanik, Fenomena Partai Keadilan, pp. 165-168. 
of franchise that offers anybody a licence to set up his own school. It simply provides a blueprint and guideline on how to establish the school. By joining JSIT, a school is administered under the auspice of the Ministry of National Education and allowed to utilize a solid curriculum constructed by JSIT. JSIT has regional and district branches across Indonesia. Every regional branch has one coordinator supervising district branch coordinators. ${ }^{38}$

To strengthen its image as a party active in humanitarian and relief operations, PKS has set up humanitarian and social units, including the Justice Post for Caring the Ummah (Pos Keadilan Peduli Ummaht), the Indonesian Red Crescent (Bulan Tsabit Merah Indonesia) and the Justice Scout (Pandu Keadilan). Through these organizations, PKS has played a crucial role to provide medical services and medicines and collect donations to be distributed to disaster victims. PKS volunteers' alertness to provide "emergency responses" was quite visible in the aftermath of the tsunami in Aceh in December 2004 as well as the earthquake in Yogyakarta and its surrounding in May 2006. They set up emergency operation centres, complete with party's symbols and emblems. In one of its media advertisements, PKS is proud to be the most committed party to people suffering from the effects of disasters. It claimed to have launched hundreds of humanitarian and relief operations, spending about US $\$ 1$ billion and US $\$ 0.2$ billion for special operation to help Palestinian Muslims. Again, PKS has been criticized by various social organizations for its hidden agenda to extend its political influence under the banner of humanitarian and relief aids.

PKS has likewise set up a fundraising-like institution called "Rumah Zakat" (Islamic alms house), through which it distributes free-interest loans. ${ }^{39}$ The Rumah Zakat has helped PKS cultivate civil society organizations operating widely to reach society at the grassroot level with the aim of providing consultancy services and advocacy for business incubation and worker associations. Through various channels, PKS has run various programmes of economic empowerment by giving soft-loans to more than 5,550 individuals and 912 independent small enterprise groups, amounting to a circulation of about Rp 6,4 billion.

\footnotetext{
${ }^{38}$ Noorhaidi Hasan, "Islamizing Formal Education: Integrated Islamic School and a New Trend in Formal Education Institution in Indonesia," RSIS Working Paper No. 172 (Singapore: S. Rajaratnam School of International Studies, 2009).

${ }^{39}$ On this institution, see http://www.rumahzakat.or.id.
} 
PKS's strategy to recruit constituents and broaden its electoral bases may resemble AKP's approach to win popular support in Turkey by providing service and performance, rather than ideology. ${ }^{40}$ Yet, PKS's concoction of da'wah, politics and social services and its aggressive penetration into the established Muslim organizations, Muhammadiyah and NU, have provoked resistance. Muhammadiyah chairman Din Syamsuddin issued a letter circulated among members about the danger of PKS towards the very existence of their organization. ${ }^{41}$ Accordingly, Muhammadiyah leadership at all branch levels have been instructed to close PKS's access to the organization's mosques and schools. ${ }^{42}$ In fact, PKS's penetration brought with it a different Salafi-style Islam and recruited a significant number of Muhammadiyah activists into its circle. This manoeuvre has shocked Muhammadiyah leadership. By recruiting Muhammadiyah activists, PKS has succeeded not only in what is called "whitening" Muhammadiyah, but also taking over some of the Muhammadiyah mosques and schools. As a consequence, fragmentation and conflict have been rife in the Muhammadiyah. ${ }^{43}$ Later, Muhammadiyah issued another letter insisting its autonomy and forbidding the utilization of Muhammadiyah facilities and its socio-educational institutions for the interest of any political parties. ${ }^{44}$ Similarly, Nahdlatul Ulama leadership decided to consolidate in order to protect their mosques and education institutions from being infiltrated by PKS. NU chairman Hasyim Muzadi repeatedly warned his members of PKS's ideological threat against Nahdlatul Ulama's principle of abl al-sunnah wa al-jama'ah. PKS has been criticized for introducing neo-Wahhabism, among other

\footnotetext{
${ }^{40}$ M. Hakan Yavuz, Secularism and Muslim Democracy in Turkey (Cambridge: Cambridge University Press, 2009).

${ }^{41}$ Marcus Mietzner, Military Politics, Islam, and the State in Indonesia, From Turbulent Transition to Democratic Consolidation (Singapore: ISEAS, 2009), pp. 239-40.

42 Surat Keputusan PP Muhammadiyah Nomor 149 Kep/1.0/b/2006 tentang Kebijakan PP Muhammadiyah tentang Konsolidasi Organisasi dan Amal Usaha.

${ }^{43}$ Lukman Hakim Arifin and Mukhlison S. Widodo, "Mendapat Tawaran dari Sales Ideologi," interview with Din Syamsuddin, Muhammadiyah Chairman, Gatra 8 (4 January 2007), http://www.gatra.com/2007-01-15/versi cetak.php?id=101186.

44 See Arif Nur Kholis, "PP Muh Terbitkan Sembilan Poin Instruksi Hadapi Pemilu 2009," http://www.muhammadiyah.or.id/index.php?option=com_content\&task=view\&id=1244.
} 
transnational ideologies considered to have shaken solidarity among NU people.

\section{The 2009 Parliamentary Elections}

PKS's campaigns to strengthen its image as a moderate Islamist party open to all segments of Indonesian society (catch-all party) intensified in the run up towards the parliamentary elections in April 2009. Although its pragmatic political standpoints have less emphasis on ideology, many voters still question whether PKS has abandoned its Islamist agenda and reconciled itself to operating within the framework of Indonesian nationalism, or whether the priority that the party had given to victory in electoral politics over a religious agenda merely represents a tactical shift in its political strategy. This sort of scepticism resonated loudly with some reservations and challenges posed by the established Muslim organizations, as noted earlier. Within this context, PKS aired a series of media advertisements. One such example is that titled "the party for all of us", in which PKS displayed a series of comments made by different people from diverse backgrounds, from an old garbage collector to a beautiful girl wearing T-shirt and jeans (without headscarf). Through these campaigns, the party sought to demonstrate its siding with a moderate version of Islam compatible with democracy. The party's elites, including the chairman of the consultative body Hilmy Aminuddin, repeatedly refuted their affinity with Wahhabism and denied their animosity towards traditional religious practices, such as tablilan, yasinan and mawludan. They also affirmed their theological affiliation with the mainstream Indonesian Islam, the abl al-sunnah wa al-jama' ah. ${ }^{45}$

In the recent legislative elections held on 9 April 2009, PKS won about 8 per cent of the overall votes, putting it at the top four after Yudhoyono's Democratic Party and the other two secular nationalist parties, Golkar and PDI-P, winning 20.45, 14.85 and 14.65 per cent respectively. Having expanded its electoral bases and launched massive media campaigns, PKS seemed disappointed with this result as its target was to win no less than 15 per cent of the vote. It is interesting

\footnotetext{
45 See the statement made by Hilmy Muhammad in a seminar in London as reported by http://www.pk-sejahtera.com, "Ketua Majelis Syuro: Saya Sering Memimpin Tahlil dan Yasin" (22 July 2008); see also "PKS Menjawab Fitnah" (25 October 2008). See also a sort of self-critique article by a PKS cadre Yon Machmudi, "PKS Mengancam Eksistensi Ormas Islam?" spread in various blog-spots.
} 
in the rest of this paper to discuss why PKS has failed to double its vote although it had run various strategies to create the image as a catch-all party concerned with the interests of the poor, youth, middle class and other segments of the Indonesian society.

Bearing in mind that the PKS's success to win 7.4 per cent of the votes in the 2004 legislative elections was contributed significantly by swing voters discontented with PDI-P founder Megawati's performance, the insignificant increase of the vote in the recent election has apparently to do with its failure to attract swing voters. As noted earlier, the rise of PKS in 2002 gave some hope among various segments of the Indonesian society refusing to support pragmatic politicians and political parties concerned solely with parliament seats and power sharing in the government. This hope has hardly materialized in tandem with PKS's increasingly pragmatic politics and its electoral, parliamentary and cabinet participation over the last five years. Accordingly, support of swing voters apparently no longer went to PKS, but rather to the Democratic Party in the recent elections. Under the party-led governing coalition, more and more people are enjoying political stability and economic recovery.

In fact, Indonesia's economic performance has improved. Gross Domestic Product (GDP) growth rose to 6.3 per cent, according to the International Monetary Fund's World Economic Outlook Database in April 2008. Foreign direct investment reached a record US $\$ 10.3$ billion in 2007, up from US $\$ 6$ billion in the previous year. As indicated by LSI's survey released in January 2009, these achievements contributed to the increase in society's satisfaction index to Yudhoyono's performance, being 62.5 per cent in dealing with economy and 63 per cent in dealing with corruption. The number is still higher in his dealing with education and health, which is 75 per cent. The Democratic Party even succeeded to create an image as the cleanest party with 11 per cent support of the respondents, compared to 9 per cent support for PKS. 46

PKS's failure to compete with the Democratic Party to win the hearts of the people can also be seen as a risk of an Islamist party which participates in the ruling coalition and yet involves in ideological and tactical compromises. As noted before, the image of the Indonesian parliament has been tarnished by corruption scandals

\footnotetext{
46 See LSI, "Swing Voter: Kecenderungan Menjelang Pemilu 2009," http://www.lsi.or.id.
} 
involving parliamentarians from Islamic parties, including PKS, and this has spread scepticism. Voter saw this kind of pragmatism as a form of hypocrisy and inconsistency to stand on the original platform of the party. They have increasingly perceived that there is no difference between secular and Islamic parties in their practices, especially when dealing with power, the government's project bids and money.

Apart from that, PKS has never dominated the control over religious symbols and interpretations, whose meanings are continuously debated by various religious actors involved in competition over who speaks for Islam. Its ideological and tactical compromises have instead reduced its identification with the symbols. This situation is not ideal for PKS especially when secular parties increasingly realized the importance of religious symbols to attract more voters. PDI-P, for instance, sought to develop its linkage with Muslim voters by setting up Baitul Muslimin Indonesia (the house of Indonesian Muslims). It is a party wing committed to Islamic education and training and helping the Indonesian Democratic Party of Struggle (PDI-P) members wanting to go on bajj to Mecca (pilgrimage). The Democratic Party developed a similar institution when Yudhoyono established Light of Peace Dhiker Council (Majelis Zikir SBY Nurussalam). Yudhoyono is the chairman of the advisory council of the organization and his own son, Edy Baskoro, acts as his secretary. Several influential personalities and businessmen around him, including Kurdi Mustafa, Hartanto Eddie Wibowo and Aziz Mochdar, serve as members of the organization's advisory council. ${ }^{47}$

The SBY dbikr council has been active to organize dbikr akbar, literally meaning the collective remembrance of God. It constitutes a devotional act in Islam that includes the chanting of divine names, supplications and aphorisms from sections of the Qur'an or from Hadith (Prophetic traditions) literature, which is performed collectively. Prayer beads upon a string, known as tasbih, and 99 in number, corresponding to the 99 names of God, are frequently used to keep track of the number of recitations that make up the dhikr. Dhiker akbar normally begins with a series of speeches delivered by high-

\footnotetext{
${ }^{47}$ See Ruslan Andy Chandra, "Yayasan Majelis Dzikir SBY Nurussalam' Publikasikan Buku," KabarIndonesia, posted on 21 August 2007; see also Rusdi Mathari, "Cahaya Keselamatan SBY," Blog Article, posted on 21 April 2008 http://rusdimathari.wordpress.com $/ 2008 / 04 / 21 /$ cahava-keselamatan-sby $/$.
} 
ranking officials, who themselves are engaged in the programme by sitting on the floor next to the ustadh (teacher) leading the participants to chant verses from the Qur'an. The role of SBY's dhikr council in the victory of the Democratic Party cannot be neglected since it is the medium through which the party's cadres strengthen their solidarity and emphasize their concern with Islam. But, being identical to the Sufi ritual, dhikr akbar expresses more esoteric dimension of Islam than the political one. This kind of ritual primarily functions to nurture and express the political stability of stratified societies upon which the legitimacy of the system and its power holders depend. 48

Nevertheless, PKS's performance in the elections is the best among Islamic parties. PAN, PKB and PPP lost between 20 and 70 per cent of their votes as garnered in the 2004 legislative elections, while PBR and PBB failed to pass the 2.5 per cent of electoral threshold. PKS apparently could remedy its loss of swing voters by effectively mobilizing support from new voters especially among the young cadres that had been engaged in da'wah activism. As participation in the da'wah also shaped the political consciousness of a younger generation of Muslims and a much broader circle, thereby creating a constituency upon which Islamist candidates could draw, PKS still has some hope to improve its performance in the next 2014 elections. PKS apparently believes that da'wah among youth is like planting seeds on a farm.

\section{Conclusion}

This paper has demonstrated that as an Islamist party that drew its inspiration from the Brotherhood-inspired tarbiyah movement, PKS has developed two paradoxical strategies whose final aim is to establish its political dominance on the landscape of the Indonesian public sphere. On one hand, it has participated in the electoral politics and launched popular campaigns in order for it to expand its electorate and the base of support and, thus, winning significant votes in the elections. Conveying alternative political visions to a wider audience, it has been active in promoting clean governance, anti-corruption and professionalism, deemed to be the prerequisite to get rid of the grasp of corruption, incompetent bureaucracy, poverty and other fundamental problems faced by Indonesia as a nation. Its ability to

48 David Kertzer, Ritual, Politics, and Power (New Haven and London: Yale University Press, 1988). 
package these issues was the key to PKS's success to garner significant votes in the 2004 parliamentary elections, capturing 7.34 per cent of the overall votes. To realize its ambition to triple this result in the 2009 parliamentary elections, PKS has continued to expand its electorate and the base of support by maximizing its all-political machine and participating in pragmatic political compromises. Through various media campaigns, PKS has also strengthened its image as a catch-all party open for all segments of Indonesian society.

No doubt, PKS's entering the electoral politics and its participation in power-sharing in parliament and government has forced it to compromise in its abstract ideals, ideology and even tactical matters. Despite the importance of the shariah as a source of identity and legitimacy in PKS's discourse, the party's politics has not been an instrument to impose the implementation of the shari'ah at the formal level. It is concerned more with the attempt to implement it through the enforcement of justice rule and good governance that can guarantee the fulfilment of civil rights. PKS has created an image as a moderate Islamist party focusing on the national agenda of realizing the nation's ideals for the sake of the burgeoning of civil society. Despite its ambivalence towards democracy, PKS has also increasingly developed an inclusive political platform and altered its basic perception about what is permissible in a democratic environment. It has no doubt learnt how to involve in the electoral democratic games and become a proactive force contributing to the process of further democratic deepening in Indonesia. Seen from this perspective, the rise of PKS in the Indonesian electoral system may represent the birth of new Islamists who hold out a longer-term vision for reform.

Nevertheless, PKS's pragmatism has not necessarily moderated its image as a party that harbours a hidden agenda to establish an Islamic state. The main problem lies in its ambition to cultivate da'wah as a complementary strategy to dominate the political landscape of Indonesia. PKS has deliberately targeted youth in these outreach activities since it has a long-term socio-political vision based on the idea of instilling in the younger generation the idea that societal reform along religiously prescribed lines is an obligation that should be pursued through civic activism. Yet, PKS's manipulation of da'wah and social services for politics and its aggressive penetration into the established Muslim organizations, Muhammadiyah and NU, have provoked resistance. Related to the dynamics of competition over who 
speaks for Islam, one remarkable nature of Muslim politics, this resistance signals the complexity of an Islamist force to dominate the political landscape of Indonesia.[]

\section{Bibliography}

\section{Books and Articles}

Abuza, Zachary. "Politics and Violence in Indonesia: An Emerging Jihadist-Islamist Nexus?" NBR Analysis 15, 3, September 2004.

al-Banna, Hasan. Risalah Pergerakan 2. Solo: Intermedia, 2001.

Baker, R. Islam Without Fear: Egypt and the New Islamists. Cambridge, MA: Harvard University Press, 2003.

Buehler, Michael. "The Rise of Shari'a Bylaws in Indonesian Districts: An Indication for Changing Pattern of Power Accumulation and Political Corruption." South East Asia Research 16, 2 (2008): pp. 255-285.

Bush, Robin. "Regional Sharia Regulations in Indonesia: Anomaly or Symptom?" in Greg Fealy and Sally White (eds). Expressing Islam, Religious Life and Politics in Indonesia. Singapore: ISEAS, 2008.

Chandra, Ruslan Andy. "Yayasan Majelis Dzikir SBY 'Nurussalam' Publikasikan Buku." Kabar Indonesia. posted on 21 August 2007

Collins, Elizabeth Fuller and Ihsan Ali Fauzi. "Islam and Democracy, the Successful New Party PKS is a Moderate Alternative to Radical Islamism.” Inside Indonesia 81 (2005)

Collins, Elizabeth Fuller. "Islam is the Solution, Dakwah and Democracy in Indonesia." Kultur, the Indonesian Journal for Muslim Cultures 3, 1 (2003): pp. 148-82

Damanik, Ali Said. Fenomena Partai Keadilan Transformasi 20 Tabun Gerakan Tarbiyah di Indonesia. Jakarta: Teraju, 2002

Dhume, Sadanand. "Radical March on Indonesia’s Future." Far Eastern Economic Review 168, 5, May 2005.

Diederich, Mathias. "A Closer Look at Dakwah and Politics in Indonesia: The Partai Keadilan.” Archipel, 64 (2002): pp. 101-15

Fuller, Graham E. The Future of Political Islam. New York: Palgrave McMillan, 2003. 
Furkon, Aay Muhammad. Partai Kedilan Sejabtera: Ideologi dan Praksis Politik Kaum Muda Muslim Indonesia Kontemporer. Jakarta: Teraju, 2004

Hasan, Noorhaidi. "Islamizing Formal Education: Integrated Islamic School and a New Trend in Formal Education Institution in Indonesia." RSIS Working Paper No. 172. Singapore: S. Rajaratnam School of International Studies, 2009.

Hasan, Noorhaidi. "Shari'a, Militancy and Democratic Consolidation in Indonesia." Working Paper No. 143. Singapore: S. Rajaratnam School of International Studies, 2007.

Hermawan, Ary. "PKS dan Perubahan Paradigma Gerakan Islam." Republika (10 April 2004.

Hosen, Nadirsyah. "Religion and the Indonesian Constitution: A Recent Debate." Journal of Southeast Asian Studies. 36, 3 (2005): pp. 419-40.

Ikhsan, Fitron Nur. "The Prosperous and Justice Party: The New Genre of Islamic Political Party in Indonesia", Unpublished $M A$ Thesis. Singapore: RSIS Nanyang Technological University, 2008

Jannah, Izzatul. Materi Tarbiyah untuk Remaja. Surakarta: Ziyad Visi Media, 2006.

Karsh, Efraim. Islamic Imperialism: A History. Yale: Yale University Press, 2006.

Kertzer, David. Ritual, Politics, and Power. New Haven and London: Yale University Press, 1988.

Machmudi, Yon. Islamising Indonesia: The Rise of Jemaah Tarbiyah and the Prosperous Justice Party. Canberra: ANU E-Press, 2008.

Mahmud, Ali Abdul Halim. Perangkat-Perangkat Tarbiyah Ikhwānul Muslimin. Solo: Intermedia, 2004.

Mandaville, Peter. Global Political Islam. London and New York: Routledge, 2007.

Mietzner, Marcus. Military Politics, Islam, and the State in Indonesia, From Turbulent Transition to Democratic Consolidation. Singapore: ISEAS, 2009. 
Öniş, Ziya. “Globalisation and Party Transformation, Turkey's Justice and Development Party in Perspective." in Peter Burnell (ed.). Globalising Democracy. London and New York: Routledge, 2007.

Permata, Ahmad-Norma. "Ideology, Institutions, Political Actions: Prosperous Justice Party (PKS) in Indonesia," Asien 19 (2008): pp. 22-36.

Piscatori, James. "Islam, Islamists and the Electoral Principle in the Middle East", ISIM Paper 1. Leiden: ISIM, 2000.

Rahmat, M. Imdadun. Ideologi Politik PKS, Dari Masjid Kampus ke Gedung Parlemen. Yogyakarta: LKiS, 2008.

Raillon, Francois. "Islam and Democracy: Indonesia's 2004 Election and Beyond", Paper presented at ELAS Special Briefing. Brussels: EIAS, 2004.

Rosyad, Rifki. A Quest for True Islam: A Study of the Islamic Resurgence Movement among Youth in Bandung, Indonesia. Canberra: ANU EPress, 2006

Salman. "The Tarbiyah Movement: Why People Join This Indonesian Contemporary Islamic Movement.” Studia Islamika 13, 2 (2006): pp. 171-241;

Surat Keputusan PP Muhammadiyah Nomor 149 Kep/1.0/b/2006 tentang Kebijakan PP. Muhammadiyah tentang Konsolidasi Organisasi dan Amal Usaha.

Tim Riset and Pengembangan Da'wahh Yayasan Darussalam. Menuju Teladan Darussalam. Yogyakarta: Daarussalaam Press, 2002.

Watt, William Montgomery. Muhammad at Medina. Oxford University Press, 1956

Widiyantoro, Nugroho. Panduan Dakwah Sekolab: Kerja Besar untuk Perubahan Besar. Bandung: Syaamil Cipta Media, 2007.

Yavuz, M. Hakan. Secularism and Muslim Democracy in Turkey. Cambridge: Cambridge University Press, 2009.

\section{Newspapers}

"PKS and the Future of RI's Democracy." Jakarta Post, 5 December 2005.

Zulkifliemansyah. "Overcoming the Fear: PKS and Democratization." The Jakarta Post, 12 December 2005. 
Wahid, Hidayat Nur. "Shari'a Should Stress Morals, Not Law." The Jakarta Post. 30 August 2007.

\section{Internet Sources}

Arifin, Lukman Hakim and Mukhlison S. Widodo. "Mendapat Tawaran dari Sales Ideologi." interview with Din Syamsuddin, Muhammadiyah Chairman, Gatra 8 (4 January 2007), http://www.gatra.com/2007-01$15 /$ versi cetak.php?id=101186.

http://www.pk-sejahtera.org.

http://www.pkswatch.blogspot.com

http://www.rumahzakat.or.id

Kholis, Arif Nur. "PP Muh Terbitkan Sembilan Poin Instruksi Hadapi Pemilu 2009." http://www.muhammadiyah.or.id/index.php?option=com_content\&task=view\&id $=1244$.

LSI. "Swing Voter: Kecenderungan Menjelang Pemilu 2009." http://www.lsi.or.id.

Mathari, Rusdi. "Cahaya Keselamatan SBY." Blog Article, posted on 21 April 2008 http://rusdimathari.wordpress.com/2008/04/21/cahaya-keselamatan-sby/

\section{Interviews}

Interview with Cholid Mahmud, one of the PKS leading figures in Yogyakarta, March 2008.

Interviews with Muhammad Khairu Mumtaz and Hamdan Subhi, Yogyakarta, February 2008.

Interviews with PKS's young cadres-Ahmad Pramono, Irfan Ahmadi, Muhammad Salahuddin-in Yogyakarta, 10-12 March 2008. 